\title{
HUBUNGAN LAJU FILTRASI GLOMERULUS DENGAN STATUS NUTRISI PADA PENDERITA PENYAKIT GINJAL KRONIK PREDIALISIS
}

\author{
Lukman Pura, ${ }^{1}$ Rudi Supriyadi, ${ }^{1}$ Gaga Irawan Nugraha, ${ }^{2}$ \\ Ria Bandiara, Rachmat Soelaeman ${ }^{1}$ \\ 'Bagian IImu Penyakit Dalam, ${ }^{2}$ Bagian IImu Gizi Medik \\ Fakultas Kedokteran Universitas Padjadjaran/ \\ Rumah Sakit Hasan Sadikin Bandung
}

\begin{abstract}
ABSTRAK
Malnutrisi banyak terjadi pada penderita penyakit ginjal kronik (PGK). Prevalensi malnutrisi pada penderita predialisis sekitar $44 \%$. Penyebab malnutrisi pada penderita PGK predialisis bersifat multifaktorial. Hubungan laju filtrasi glomerulus (LFG) dengan status nutrisi gabungan menggunakan albumin serum, indeks massa tubuh (IMT) dan subjective global assessment (SGA) masih belum banyak diteliti. Penelitian ini bertujuan mencari hubungan LFG dengan parameter nutrisi gabungan pada subjek PGK predialisis yang berkunjung ke poliklinik ginjal hipertensi RS Hasan Sadikin Bandung dari bulan September sampai Oktober 2008. Data sekunder dan primer dikumpulkan secara konsekutif. Pemeriksaan meliputi penilaian klinis, laboratorium, dan LFG dengan metode in vivo. Analisis statistik menggunakan uji Mann-Whitney untuk melihat hubungan LFG dengan status nutrisi gabungan dengan multiple utility assessment criteria (MUAC). Tujuh puluh dua subjek terdiri dari 48 laki-laki dan 24 perempuan memenuhi kriteria penelitian. Sebanyak $79,2 \%$ subjek dengan usia di atas 50 tahun dan $54,2 \%$ dengan penyebab sakit hipertensi. Rata-rata LFG $32,62 \mathrm{~mL} / \mathrm{mnt}$, albumin serum $4,10 \mathrm{~g} / \mathrm{dL}$ dan IMT 23,87 kg/m² . Terdapat $80,6 \%$ subjek dengan status gizi buruk dan 19,4\% dengan gizi baik. Menggunakan metode MUAC, 70 subjek dengan kategori gizi baik dan 2 subjek dengan gizi buruk. Hubungan LFG terhadap parameter nutrisi ditentukan dengan uji Rank-Spearman dan hasil tidak bermakna terhadap semua variabel nutrisi $(p>0,05)$. Hubungan LFG terhadap parameter nutrisi gabungan memberikan hasil tidak bermakna $(p>0,05)$. Kesimpulan: terdapat hubungan yang sangat kecil antara LFG terhadap perubahan parameter nutrisi gabungan, dengan jumlah sampel 72 subjek tidak dapat mendeteksi adanya hubungan yang bermakna.
\end{abstract}

Kata kunci: PGK, LFG, albumin serum, IMT, SGA

\section{THE CORRELATION BETWEEN GLOMERULAR FILTRATION RATE (GFR) AND NUTRITIONAL STATUS INPEDIALYTIC CHRONIC KIDNEY DISEASE PATIENTS}

\begin{abstract}
Protein-energy malnutrition (PEM) is common in chronic kidney disease (CKD) patients. The prevalence of malnutrition in predialytic patients was approximately $44 \%$. The causes of malnutrition in CKD patients are multifactorial. The correlation of glomerular filtration rate (GFR) and combined nutritional parameter such as serum albumin, body mass index (BMI) and subjective global assessment (SGA) is more need to study. The study aimed to find the correlation GFR and the combined nutritional parameter in predialytic CKD patients who attended the Nephrology-Hypertension Clinic of Hasan Sadikin Hospital between September and October 2008. The secondary and primary data were collected consecutively. The evaluation consisted of clinical assessment of nutritional status, laboratory values, and GFR by in vivo method. The combined nutritional parameter was classified into two groups using multiple utility assessment criteria (MUAC). Statistical analysis with Mann-Whitney test was used to find the correlation. Seventy two subjects (48 men and 24 women) fulfilled the criteria. The majority $(79.2 \%)$ were older than 50 years old and $54.2 \%$ the causes of CKD were hypertension. The median GFR was $32.62 \mathrm{~mL} / \mathrm{mnt}$, serum albumin was $4.10 \mathrm{~g} / \mathrm{dL}$, and BMI was $23.87 \mathrm{~kg} / \mathrm{m}^{2}$. There were $80.6 \%$ subjects with malnourished status, $19.4 \%$ with normal status. Using MUAC assessment, 70 subjects with normal nutritional status and 2 with severe malnutrition.We found no significant correlation between GFR and any nutritional parameter $(p>0.05)$. The correlation of GFR and combined nutritional parameter was not significant $(p>0.05)$. Conclusion: There is minimal correlation of GFR and combined nutritional parameter, with 72 samples size the correlation cannot be detected significantly.
\end{abstract}

Key words: CKD, GFR, serum albumin, BMI, SGA

\author{
Alamat Korespondensi \\ dr. Lukman Pura, MHSM.,Sp.PD \\ Subbagian Ginjal-Hipertensi Bagian Ilmu Penyakit Dalam \\ Fakultas Kedokteran Universitas Padjadjaran/RS Hasan Sadikin Bandung. \\ Jl. Pasteur No.38 Bandung, Telp: 08122009135, Email: pura.lukman@yahoo.com
}




\section{PENDAHULUAN}

Penyakit ginjal kronik (PGK) adalah suatu keadaan terjadinya kerusakan ginjal secara perlahan dan progresif disertai dengan kehilangan fungsi ginjal dalam kurun waktu tertentu. Kelainan yang ditemukan dapat secara struktural akibat kelainan patologis organ, adanya benda asing, atau adanya kelainan fungsional ginjal. ${ }^{1-3}$ Pada saat laju filtrasi glomerulus (LFG) menurun di bawah rata-rata fungsi normalnya, maka fungsi tersebut cenderung akan terus menurun. ${ }^{1}$ Perjalanan penyakit ginjal kronik yang progresif akan melewati fase-fase tertentu yang menggambarkan menurunnya fungsi dari kondisi yang paling ringan, sedang atau berat dan berakhir dengan timbulnya gagal ginjal terminal. ${ }^{1,2}$

Penyakit ginjal kronik yang progresif dapat merubah asupan kalori dan protein. ${ }^{1,4}$ Penurunan laju filtrasi glomerulus akan menurunkan asupan protein dan energi akibat meningkatnya akumulasi toksin uremikum yang menyebabkan perubahan pola makan karena terjadinya anoreksia. ${ }^{5-8}$ Kebutuhan dan metabolisme beberapa nutrisi tubuh berubah secara signifikan, sebagai contoh adalah akibat restriksi asupan protein yang dilakukan untuk mengurangi akumulasi ureum yang berasal dari katabolisme protein. Selain itu terjadi pula perubahan metabolisme asam amino yang dibentuk di ginjal akibat penyakit ginjal kronik itu sendiri, seperti arginin, serin, dan tirosin. ${ }^{7,8}$ Perubahan ini menyebabkan penderita mempunyai risiko tinggi untuk terjadinya protein-calory malnutrition (PEM) atau malnutrisi. ${ }^{5,-9}$

Malnutrisi banyak terjadi pada penderita penyakit ginjal kronik. Prevalensi malnutrisi pada penderita predialisis sekitar $44 \% .{ }^{10}$ Penyebab malnutrisi pada penderita penyakit ginjal kronik khususnya predialisis bersifat multifaktorial antara lain inflamasi, asupan protein energi yang menurun, asidosis metabolik, adanya penyakit penyerta, dan gangguan hormonal. ${ }^{11-13}$

Penurunan laju filtrasi glomerulus $(<60$ $\mathrm{mL} /$ menit/1,73 $\mathrm{m}^{2}$ ) menyebabkan penurunan kemampuan bersihan (klirens) ginjal sehingga terjadi penumpukan bahan-bahan toksik (uremia). ${ }^{14,15}$ Timbulnya uremia disertai dengan peningkatan sitokin inflamasi dalam tubuh menyebabkan anoreksia yang mempengaruhi asupan makanan, dan hal ini merupakan penyebab penting timbulnya malnutrisi. Di samping itu restriksi protein yang dilakukan juga mempercepat terjadinya malnutrisi. ${ }^{9,16-18}$

Malnutrisi dan inflamasi pada penderita gagal ginjal kronik predialisis digunakan sebagai prediktor luaran penderita, baik prognosis perjalanan penyakitnya, kemungkinan komplikasi yang timbul, maupun kualitas hidup penderita selanjutnya. ${ }^{3,7,8,11,19}$

Banyak metode pemeriksaan atau para- meter untuk menilai status nutrisi, namun tidak ada satupun cara penilaian yang dapat menggambarkan secara sempurna status nutrisi penderita. Penilaian awal status nutrisi seharusnya terus dilakukan secara dinamis dengan menggunakan cara yang cepat, akurat, efisien, dan dapat dilakukan dengan mudah. subjective global assessment (SGA) dengan parameter biokimia darah (albumin serum) serta pemeriksaan antropometri merupakan metode yang dapat digunakan dan direkomendasikan. ${ }^{7,20-23}$

Malnutrisi dan inflamasi berinteraksi dalam progresivitas perjalanan PGK dan terbentuknya proses aterosklerosis. Pemahaman tentang proses patofisologi dan interaksi tersebut dapat mencegah atau memperlambat perjalanan penyakit dan komplikasi yang lebih berat. $^{7,8,11,19}$ Komplikasi yang sering timbul pada populasi penderita PGK adalah komplikasi kardiovaskular. Peningkatan sitokin inflamasi, banyaknya penyakit penyerta, dampak dari malnutrisi menyebabkan disfungsi organ secara kronik (endothelial damage) dan peningkatan beban kerja kardiovaskular sehingga mempercepat komplikasi yang terjadi (ischemic heart disease). Kaitan antara komplikasi tersebut pada penderita gagal ginjal kronik dikenal sebagai malnutrition inflammation and atherosclerosis syndrome (MIA syndrome). ${ }^{17,19,24-27}$

\section{METODE}

Subjek penelitian adalah penderita penyakit ginjal kronik yang berkunjung ke Poliklinik Ginjal Hipertensi serta Poliklinik IImu Penyakit Dalam Pria dan Wanita Bagian IImu Penyakit Dalam Fakultas Kedokteran Universitas Padjadjaran/ RS. Hasan Sadikin Bandung yang belum menjalani hemodialisis. Subjek diberikan keterangan yang lengkap dan jelas tentang penelitian yang akan dilakukan dan diperoleh informed consent dari subjek, selanjutnya dilakukan penyaringan subjek melalui anamnesis, pemeriksaan fisis, dan pemeriksaan laboratorium.

Kriteria inklusi adalah semua penderita penyakit ginjal kronik dewasa yang belum menjalani dialisis dan semua penderita penyakit ginjal kronik dewasa dengan proteinuria maksimal positif 2 serta bersedia untuk mengikuti penelitian. Kriteria eksklusi adalah penderita penyakit ginjal kronik dengan nefrotik proteinuria, dan tidak menderita penyakit sirosis hepatis, tuberkulosis, atau gagal jantung bendungan.

Penelitian ini merupakan penelitian observasional dengan rancangan cross sectional disertai dengan pengkajian analitik. Penelitian ini akan melihat hubungan tingkat penurunan laju LFG penderita penyakit ginjal kronik predialisis terhadap parameter status nutrisi yaitu IMT, albumin, dan SGA.

Variabel yang dipakai antara lain: varia- 
bel independen (bebas) pada penelitian ini adalah LFG; variabel dependen (terikat) pada penelitian ini adalah parameter status nutrisi terdiri dari albumin serum, indeks massa tubuh (IMT), dan subjective global assessment (SGA); variabel perancu (confounding) pada penelitian ini adalah penyebab penyakit ginjal kronik, penyakit penyerta (comorbid) (sirosis, TB, gagal jantung) dan penyulitnya, usia, jenis kelamin, dan berat badan.

Pengambilan sampel dilakukan secara berurutan (consecutive admissions), dan setiap penderita yang berkunjung ke Poliklinik Ginjal Hipertensi dan Poliklinik IImu Penyakit Dalam Pria dan Wanita akan mempunyai kesempatan yang sama untuk menjadi sampel penelitian, sampai tercapai jumlah populasi penelitian yang dikehendaki.

Data yang dikumpulkan merupakan data primer dan data sekunder dari penelitian sebelumnya yang meliputi identitas umum terdiri dari jenis kelamin, tingkat pendidikan, pekerjaan serta data lainnya yaitu diagnosis penyakit, tinggi badan, berat badan, kadar albumin serum, nilai SGA, dan nilai LFG. Data diperoleh melalui wawancara, pemeriksaan fisis, dan pengambilan darah sesuai kebutuhan penelitian. Seluruh parameter yang dikumpulkan didefinisikan secara operasional sebagaimana tampak pada Tabel 1.

Data primer dan sekunder yang terkumpul dari subjek penelitian akan dikelompokkan sesuai dengan stadium penyakit ginjal kronik berdasarkan LFG-nya. Kemudian dihitung dan dinilai status nutrisi masing-masing subjek berdasarkan peniliaian SGA yang dikelompokkan dalam SGAA, SGA B, SGA C, dan IMT serta albumin serum. Laju filtrasi glomerulus merupakan variabel independen yang memprediksi derajat status nutrisi yang merupakan composite variables (gabungan) antara IMT, SGA, dan albumin serum.

Untuk melihat hubungan LFG dengan masing-masing parameter nutrisi dilakukan analysis bivariate terhadap albumin serum, IMT, dan SGA (Rank-Spearman test). Pengolahan data selanjutnya dengan uji Mann-Whitney untuk melihat hubungan LFG terhadap parameter status nutrisi gabungan (composite variables) terdiri dari albumin serum, IMT, dan SGA yang telah dikelompokkan menjadi dua kategori baik dan buruk dengan metode MUAC (Tabel 1).

\section{HASIL}

Hubungan LFG dengan status nutrisi pada penderita penyakit ginjal kronik predialisis dilakukan dalam kurun waktu dua bulan terhadap subjek penelitian yang berkunjung ke Poliklinik Ginjal Hipertensi dan Poliklinik
Penyakit Dalam Pria dan Wanita Rumah Sakit dr.Hasan Sadikin Bandung. Jumlah subjek yang masuk dalam penelitian ini adalah 72 subjek. Pada semua subjek yang memenuhi kriteria penelitian dilakukan wawancara untuk pengumpulan data umum yang meliputi, jenis kelamin, usia, tingkat pendidikan, pekerjaan, penyakit yang diderita, dan selanjutnya dilakukan pemeriksaan fisis dan pengambilan darah untuk pengukuran status nutrisi dan pemeriksaan laju filtrasi glomerulus.

Pada data kuantitatif telah dilakukan uji normalitas dengan uji Kolmogorov Smirnov untuk memenuhi uji statistik yang sesuai. Karakteristik jenis kelamin menunjukkan dua per tiga subjek adalah laki-laki $(66,7 \%)$ dan wanita sebanyak 33,3\%. Karakteristik usia subjek, sebagian besar penderita berusia di atas 50 tahun sejumlah 57 subjek $(79,2 \%)$. Karakteristik pekerjaan subjek hampir terbagi sama antara PNS dan pekerjaan lainnya (tidak bekerja/IRT, buruh, atau swasta lainnya) masing-masing $56,9 \%$ dan $43,1 \%$. Penyebab utama penyakit ginjal pada subjek penelitian sebagian besar disebabkan oleh hipertensi (vascular disease) diikuti oleh penyakit tubulus (tubulointerstitial disease) dan glomerulonefritis kronik masingmasing sebesar $54,2 \%, 27,8 \%$, dan $18,1 \%$.

Karakteristik parameter nutrisi subjek sebagian besar $(90,3 \%)$, mempunyai IMT $>18,5$ $\mathrm{kg} / \mathrm{m}^{2}$ dan albumin serum $>3,5 \mathrm{~g} / \mathrm{dL}(91,7 \%)$. Berdasarkan penilaian SGA sebanyak 58 subjek $(80,6 \%)$ dengan status malnutrisi sedang-buruk (SGA B dan C) dan hanya 14 subjek $(19,4 \%)$ dengan status nutrisi normal (SGA A).

\section{Karakteristik Berbagai Variabel}

Tabel 3 menunjukkan LFG seluruh subjek penelitian dengan rata-rata $32,62 \mathrm{~mL} / \mathrm{mnt}$, nilai ini tidak berbeda jauh dengan nilai tengah yang dihasilkan sebesar $31,39 \mathrm{~mL} / \mathrm{mnt}$ dengan rentang nilai LFG terukur berkisar dari 0,00 (ginjal tidak berfungsi) sampai $88,00 \mathrm{~mL} / \mathrm{mnt}$. Berdasarkan kriteria penyakit ginjal kronik (PGK) dan melihat nilai rata-rata maka sebagian penderita masih dalam stadium 3 PGK (30-59 $\mathrm{mL} / \mathrm{mnt} / 1,73 \mathrm{~m}^{2}$ ). Albumin serum subjek masih dalam rentang nilai normal dengan rata-rata nilai $4,10 \mathrm{~g} / \mathrm{dL}$ dengan rentang nilai terukur antara 2,25-5,27 g/dL. Hasil pengukuran IMT subjek memberikan rata-rata nilai normal tinggi 23,87 $\mathrm{kg} / \mathrm{m}^{2}$ dengan kisaran nilai 15,23 sampai 31,63 $\mathrm{kg} / \mathrm{m}^{2}$.

\section{Karakteristik Nilai Laju Filtrasi Glomerulus (LFG) dari Berbagai Parameter yang Diukur}

LFG terhadap masing-masing parameter nutrisi yang telah dikelompokkan sesuai kebutuhan penelitian tampak pada Tabel 4. Nilai LFG pada parameter nutrisi gabungan juga ditentukan 
Tabel 1 Definisi Operasional Variabel

\begin{tabular}{|c|c|c|c|c|c|}
\hline Variabel & $\begin{array}{c}\text { Definisi } \\
\text { Operasional }\end{array}$ & Alat Ukur & Cara Ukur & Skala & Hasil Ukur \\
\hline Albumin & $\begin{array}{l}\text { Kadar cadangan protein } \\
\text { darah (viseral) yang } \\
\text { menggambarkan status } \\
\text { nutrisi berdasarkan } \\
\text { pemeriksaan biokimia }\end{array}$ & -Fotometer & $\begin{array}{l}\text {-Pemeriksaan } \\
\text { serum } \\
\text { darah }\end{array}$ & Rasio & $-g / d L$ \\
\hline $\begin{array}{l}\text { Indeks } \\
\text { massa tubuh } \\
\text { (IMT/BMI) }\end{array}$ & $\begin{array}{l}\text { Penilaian massa otot } \\
\text { tubuh berdasarkan } \\
\text { metode antropometri } \\
\text { dengan membagi berat } \\
\text { badan }(\mathrm{kg}) \text { dengan tinggi } \\
\text { badan kuadrat }(\mathrm{m})^{2}\end{array}$ & $\begin{array}{l}\text {-Alat ukur } \\
\text { standar tinggi } \\
\text { badan } \\
\text { (stature meter) } \\
\text {-Alat timbang } \\
\text { badan berdiri }\end{array}$ & $\begin{array}{l}\text {-Berat badan } \\
\text { berdiri } \\
\text {-Tinggi badan } \\
\text { berdiri }\end{array}$ & Rasio & $\begin{array}{l}\text { - kilogram }(\mathrm{kg}) \\
\text { - meter }(\mathrm{m})\end{array}$ \\
\hline $\begin{array}{l}\text { Subjective } \\
\text { Global } \\
\text { Assessment } \\
\text { (SGA) }\end{array}$ & $\begin{array}{l}\text { Penilaian status nutrisi } \\
\text { secara klinis } \\
\text { berdasarkan riwayat } \\
\text { medis, gejala klinis, dan } \\
\text { pemeriksaan fisis }\end{array}$ & Wawancara & $\begin{array}{l}\text {-Wawancara } \\
\text { Medis } \\
\text {-Pemeriksaan } \\
\text { Fisis }\end{array}$ & Ordinal & $\begin{array}{l}\text {-SGA A (Normal) } \\
\text {-SGA B (Malnut. } \\
\text { rngn-sdg) } \\
\text {-SGA C } \\
\text { (Malnutrisi berat) }\end{array}$ \\
\hline $\begin{array}{l}\text { Laju Filtrasi } \\
\text { Glomerulus } \\
\text { (LFG) }\end{array}$ & $\begin{array}{l}\text { Penilaian fungsi ginjal } \\
\text { subjek yang } \\
\text { berhubungan dengan } \\
\text { stadium penyakit ginjal } \\
\text { kronik (PGK) }\end{array}$ & $\begin{array}{l}\text {-Kamera gama } \\
\text { (Kedokteran } \\
\text { Nuklir) }\end{array}$ & $\begin{array}{l}\text {-Radiofarmaka } \\
\text { (In Vivo) }\end{array}$ & Rasio & $-\mathrm{mL} / \mathrm{mnt} / 1,73 \mathrm{~m}^{2}$ \\
\hline $\begin{array}{l}\text { Jenis } \\
\text { Kelamin }\end{array}$ & $\begin{array}{l}\text { Perbedaan seks yang } \\
\text { membedakan antara pria } \\
\text { dan wanita }\end{array}$ & Wawancara & $\begin{array}{l}\text {-Wawancara } \\
\text {-Observasi }\end{array}$ & Ordinal & $\begin{array}{l}\text { - Laki-Laki } \\
\text {-Perempuan }\end{array}$ \\
\hline Usia & $\begin{array}{l}\text { Usia penderita } \\
\text { berdasarkan tanggal, } \\
\text { bulan dan tahun } \\
\text { kelahiran pada saat } \\
\text { wawancara }\end{array}$ & Wawancara & $\begin{array}{l}\text {-Wawancara } \\
\text {-Observasi } \\
\text { (KTP) }\end{array}$ & Ordinal & $\begin{array}{l}\text { - Lansia } \\
\quad(\geq 65 \text { th }) \\
\text {-Tua } \\
\quad(<65 \text { th })\end{array}$ \\
\hline $\begin{array}{l}\text { Tingkat } \\
\text { Pendidikan }\end{array}$ & $\begin{array}{l}\text { Pendidikan tertinggi } \\
\text { formal yang dicapai } \\
\text { subjek pada saat } \\
\text { wawancara }\end{array}$ & Wawancara & $\begin{array}{l}\text { - Wawancara } \\
\text {-Observasi } \\
\text { (KTP) }\end{array}$ & Ordinal & $\begin{array}{l}\text { - Tinggi } \\
\text { - Rendah }\end{array}$ \\
\hline Pekerjaan & $\begin{array}{l}\text { Pekerjaan yang dijalani } \\
\text { subjek secara terus } \\
\text { menerus dalam } 6 \text { bulan } \\
\text { terakhir }\end{array}$ & Wawancara & $\begin{array}{l}\text { - Wawancara } \\
\text {-Observasi } \\
\text { (KTP) }\end{array}$ & Ordinal & $\begin{array}{l}\text { - PNS } \\
\text {-Lain-lain } \\
\text { (buruh,swasta, } \\
\text { IRT) }\end{array}$ \\
\hline
\end{tabular}

dengan melakukan pembobotan menggunakan metode multiple utility assessment criteria (MUAC) terhadap masing-masing parameter untuk kemudian dikelompokkan dalam status nutrisi baik dan buruk, sebagaimana tercantum dalam definisi operasional variabel.

Laju filtrasi (LFG) rata-rata subjek lakilaki lebih besar dibandingkan dengan perempuan masing-masing $34,08 \mathrm{~mL} / \mathrm{mnt}$ dan 29,71 $\mathrm{ml} / \mathrm{mnt}$. Berdasarkan diagnosis penyakit, penderita dengan penyebab hipertensi (HRD) memiliki LFG yang lebih tinggi dengan rata-rata 34,52 $\mathrm{mL} / \mathrm{mnt}$. Menurut usia subjek penelitian, penderita PGK dengan usia yang lebih tua ( $\geq 65$ tahun) masih memiliki LFG yang lebih tinggi yakni sebesar $34,57 \mathrm{~mL} / \mathrm{mnt}$ dibandingkan dengan usia lainnya.

Laju filtrasi glomerulus yang dihubungkan dengan masing-masing parameter nutrisi yang dikelompokkan sesuai kebutuhan penelitian, subjek dengan SGA buruk (B dan C) mempunyai LFG tidak berbeda jauh dengan
SGA baik (SGA A), masing-masing 32,96 $\mathrm{mL} / \mathrm{mnt}$ dan $32,54 \mathrm{~mL} / \mathrm{mnt}$. Subjek dengan kadar albumin serum $\geq 3,5 \mathrm{~g} / \mathrm{dL}$ mempunyai nilai LFG yang tidak jauh berbeda dengan subjek yang mempunyai kadar albumin kurang dari $3,5 \mathrm{~g} / \mathrm{dL}$ masing masing $32,76 \mathrm{~mL} / \mathrm{mnt}$ dan $31,10 \mathrm{~mL} / \mathrm{mnt}$. Subjek dengan IMT $\geq 18,5 \mathrm{~kg} / \mathrm{m}^{2}$ mempunyai LFG sebesar $33,72 \mathrm{~mL} / \mathrm{mnt}$, berbeda dengan subjek yang memiliki IMT $\geq 18.5 \mathrm{~kg} / \mathrm{m}^{2}$ mempunyai nilai LFG $22,52 \mathrm{~mL} / \mathrm{mnt}$. Besarnya nilai LFG pada parameter status nutrisi gabungan seluruh subjek berbeda pada subjek dengan status gizi baik dan gizi buruk masing masing mempunyai nilai LFG $33,05 \mathrm{~mL} / \mathrm{mnt}$ dan $17,54 \mathrm{~mL} / \mathrm{mnt}$.

\section{Korelasi LFG Terhadap Masing-masing Parameter Nutrisi dan Parameter Nutrisi Gabungan (MUAC)}

Albumin serum, IMT, dan SGA adalah parameter yang digunakan untuk menilai status nutrisi pada 
Tabel 2 Karakteristik Umum Subjek Penelitian ( $n=72)$

\begin{tabular}{llll}
\hline Karakteristik & Jenis Kategori & Jumlah & $\%$ \\
\hline Jenis Kelamin & Laki-laki & 48 & 66,7 \\
Usia (thn) & Perempuan & 24 & 33,3 \\
& $<50$ & 15 & 20,8 \\
& $50-64$ & 30 & 41,7 \\
Pekerjaan & $>65$ & 27 & 37,5 \\
& Tidak Bekerja & 17 & 23,6 \\
& P N S & 41 & 56,9 \\
& Swasta & 3 & 4,2 \\
Ideks Massa Tubuh & Buruh & 11 & 15,3 \\
(IMT) (kg/m ${ }^{2}$ ) & $\geq 18,5$ & 7 & 9,7 \\
Albumin (g/dL) & $<3,5$ & 65 & 90,3 \\
& $\geq 3,5$ & 6 & 8,3 \\
Subjective Global & Buruk & 66 & 91,7 \\
Assessment (SGA) & Baik & 58 & 80,6 \\
& A & 14 & 19,4 \\
& B & 14 & 19,4 \\
& C & 27 & 37,5 \\
Diagnosis & Hipertensi & 31 & 43,1 \\
Penyebab PGK & Pielonefritis Kronik & 20 & 54,2 \\
& Glomerulonefritis & 13 & 27,6 \\
\hline
\end{tabular}

Tabel 3 Karakteristik Nilai LFG, Albumin Serum, dan IMT ( $n=72)$

\begin{tabular}{llccc}
\hline \multicolumn{1}{c}{ Variabel } & $\mathbf{X}$ & SD & Median & Rentang \\
\hline Laju Filtrasi Glomerulus $(\mathrm{mL} / \mathrm{mnt})$ & 32,62 & 18,45 & 31,39 & $00,00-88,00$ \\
Albumin $(\mathrm{g} / \mathrm{dL})$ & 4,10 & 0,52 & 4,18 & $02,25-05,27$ \\
Indeks Massa Tubuh $\left(\mathrm{kg} / \mathrm{m}^{2}\right)$ & 23,87 & 3,94 & 23,65 & $15,23-31,63$ \\
\hline
\end{tabular}

Tabel 4 Deskripsi Ukuran Statistik LFG dari Variabel yang Diukur $(n=72)$

\begin{tabular}{|c|c|c|c|c|c|c|}
\hline \multirow{2}{*}{ Variabel } & \multirow{2}{*}{$\begin{array}{c}\text { Jenis } \\
\text { Kategori }\end{array}$} & \multicolumn{5}{|c|}{ Laju Filtrasi Glomerulus (LFG)(mL/mnt) } \\
\hline & & $\mathbf{n}$ & $\bar{X}$ & SD & Median & Rentang \\
\hline Jenis & Laki-lak & 48 & 34,08 & 18,87 & 31,40 & $0,00-88,00$ \\
\hline Kelamin & Perempuan & 24 & 29,71 & 17,60 & 30,80 & 0,00-76,08 \\
\hline \multirow[t]{3}{*}{ Diagnosis } & Hipertensi & 39 & 34,52 & 18,07 & 31,76 & $3,00-81,24$ \\
\hline & Pielonefritis Kronik & 20 & 28,09 & 15,60 & 30,40 & $0,00-58,34$ \\
\hline & Glomerulonefritis & 13 & 33,91 & 23,39 & 31,41 & $0,00-88,00$ \\
\hline \multirow[t]{2}{*}{ SGA } & Baik & 14 & 32,96 & 21,31 & 30,03 & $9,00-88,00$ \\
\hline & Buruk & 58 & 32,54 & 17,90 & 31,39 & $0,00-81,21$ \\
\hline Albumin & $\geq 3,5$ & 66 & 32,76 & 18,73 & 30,48 & $0,00-88,00$ \\
\hline$(g / d L)$ & $\overline{<} 3,5$ & 6 & 31,10 & 16,47 & 33,25 & $0,00-47,60$ \\
\hline \multirow[t]{2}{*}{ IMT(kg/m²) } & $\geq 18,5$ & 65 & 33,71 & 17,88 & 31,41 & $3,00-88,00$ \\
\hline & $<18,5$ & 7 & 22,52 & 22,00 & 30,57 & $0,00-51,43$ \\
\hline \multirow[t]{3}{*}{ Usia (th) } & $<50$ & 15 & 29,72 & 25,88 & 30,40 & $0,00-88,00$ \\
\hline & $50-64$ & 30 & 32,32 & 15,25 & 32,36 & $3,00-75,72$ \\
\hline & $\geq 65$ & 27 & 34,57 & 17,33 & 30,24 & $9,43-81,21$ \\
\hline \multirow[t]{2}{*}{ MUAC } & Baik & 70 & 33,05 & 18,29 & 31,39 & $0,00-88,00$ \\
\hline & Buruk & 2 & 17,54 & 24,81 & 17,54 & $0,00-35,09$ \\
\hline
\end{tabular}

Tabel 5 Korelasi Antara LFG Terhadap Masing-Masing Parameter Nutrisi (Umum)

\begin{tabular}{lcc}
\hline $\begin{array}{l}\text { Korelasi GFR } \\
\text { Terhadap }\end{array}$ & $\mathbf{r}_{\mathbf{s}}$ & $\begin{array}{c}\text { Nilai } \\
\mathbf{p}\end{array}$ \\
\hline Albumin serum & 0,012 & 0,919 \\
IMT & 0,101 & 0,399 \\
SGA & 0,109 & 0,361 \\
\hline
\end{tabular}


Tabel 6 Hubungan Nilai LFG Berdasarkan Parameter Nutrisi Gabungan (MUAC) ( $n=72$ )

\begin{tabular}{|c|c|c|c|c|}
\hline \multirow[b]{2}{*}{ LFG } & \multicolumn{2}{|c|}{ MUAC } & \multirow[b]{2}{*}{$\mathbf{Z}_{\mathrm{M}-\mathrm{W}}$} & \multirow[b]{2}{*}{$\begin{array}{c}\text { Nilai } \\
\text { p }\end{array}$} \\
\hline & $\begin{array}{c}\text { Baik } \\
(n=70)\end{array}$ & $\begin{array}{c}\text { Buruk } \\
(n=2)\end{array}$ & & \\
\hline $\bar{X}(S D)$ & $\begin{array}{l}33,05 \\
(18,29)\end{array}$ & $17,54(24,81)$ & 0,857 & 0,392 \\
\hline $\begin{array}{l}\text { Median } \\
\text { Rentang }\end{array}$ & $\begin{array}{l}31,39 \\
0,00-88,00\end{array}$ & $\begin{array}{l}17,54 \\
0,00-35,09\end{array}$ & & \\
\hline
\end{tabular}

Keterangan: $Z_{\text {M-W }}$ Uji Mann-Whitney

subjek penelitian, masing-masing menggambarkan status protein viseral tubuh (biokimia), status cadangan otot (lean body mass), dan status penilain klinis. Uji Rank-Spearman digunakan untuk mencari korelasi masingmasing parameter terhadap LFG. Korelasi LFG terhadap status nutrisi albumin serum tidak bermakna $\left(r_{s}=0,012 ; p>0,05\right)$, terhadap IMT memberikan hasil tidak bermakna $\left(r_{s}=0,101 ; p>\right.$ $0,05)$ dan terhadap penilaian SGA juga tidak bermakna $\left(r_{s}=0,109 ; p>0,05\right)$, masing-masing korelasi tersebut tampak pada Tabel 5 .

Hubungan besarnya nilai antara laju filtrasi glomerulus dan parameter nutrisi gabungan yang telah dilakukan pembobotan (MUAC) terhadap masing-masing parameter nutrisi. Uji statistik Mann-Whitney digunakan untuk melihat korelasi LFG terhadap status nutrisi gabungan. Hasil perhitungan dengan uji tersebut memberikan hubungan tidak bermakna dengan $Z_{M-w}=$ 0,$857 ; p>0,392 \quad(p>0,05)$. Korelasi tersebut tampak pada Tabel 6 .

\section{Hubungan LFG Terhadap Kelompok pada Masing-masing Parameter Nutrisi}

Nilai LFG selanjutnya ditentukan untuk melihat hubungan berdasarkan masing-masing parameter nutrisinya yang dikelompokkan sesuai kebutuhan penelitian dalam kriteria status nutrisi baik dan buruk. Hasil perhitungan dengan uji MannWhitney menunjukkan hubungan tersebut tidak bermakna terhadap masing-masing parameter dengan nilai masing-masing SGA $\left(Z_{M-w}=0,235\right.$; $p>0,05)$, albumin serum $\left(Z_{M-W}=0,377 ; p>0,05\right)$ dan indeks massa tubuh (IMT) $\left(Z_{M-w}=1,017\right.$; $p>0,05)$ (tabel tidak ditampilkan).

\section{PEMBAHASAN}

Berdasarkan hasil penelitian di atas diketahui bahwa karakteristik umum subjek penelitian (Tabel 2) sebagian besar adalah laki-laki dan usia rata-rata di atas 50 tahun dengan penyebab terbanyak penyakit ginjal kronik adalah hipertensi. Variabel utama yang diukur menunjukkan bahwa hampir semua subjek mempunyai status gizi baik berdasarkan kriteria nilai albumin serum dan indeks massa tubuh. Namun sebaliknya berdasarkan kriteria penilaian SGA, sebagian besar subjek masuk dalam kriteria malnutrisi (SGA B dan C).

Hal tersebut di atas mungkin terjadi mengingat penilaian SGA berdasarkan parameter anamnesis dan gejala klinis memberikan nilai sensitivitas yang tinggi dalam mendeteksi kemungkinan terjadinya malnutrisi. Demikian sebaliknya hubungan antara albumin serum dan indeks massa tubuh yang menggambarkan status nutrisi baik, tidak berarti berhubungan secara linier. Penelitian yang dilakukan Koople dkk. ${ }^{16}$ pada studi MDRD terhadap populasi penderita penyakit ginjal kronik menunjukkan bahwa beberapa parameter nutrisi (antropometri) termasuk indeks massa tubuh saling berkorelasi secara signifikan satu sama lainnya (lingkar lengan atas, ketebalan lemak kulit, berat badan standar), namun tidak menunjukkan korelasi yang linier terhadap protein viseral (albumin, transferin). Hal ini mungkin disebabkan karena faktor-faktor yang mempengaruhi kedua jenis parameter tersebut berbeda. Demikian pula hubungan IMT terhadap SGA, penelitian Stenvinkel dkk. ${ }^{5}$ menunjukkan bahwa penderita dengan SGA malnutrisi banyak terdapat pada pasien yang mempunyai IMT normal $(45 \%)$ atau dengan IMT > $25 \mathrm{~kg} / \mathrm{m}^{2}(17 \%)$. Sebaliknya, didapatkan sebanyak $38 \%$ penderita dengan IMT tergolong dengan hasil penilaian SGA normal. ${ }^{10}$

Nilai laju filtrasi glomerulus (LFG) pada berbagai variabel yang diukur tidak berbeda jauh dengan nilai LFG rata-rata penelitian (Tabel 3 dan 4). Berdasarkan kriteria $\mathrm{DOQ}{ }^{3}$ rata-rata LFG masuk dalam kriteria stadium 3 penyakit ginjal kronik (PGK). Kadar albumin serum dan indeks massa tubuh (IMT) rata-rata subjek penelitian masih dalam batas normal (Tabel 3). Berbeda dengan hasil penelitian yang dilakukan Stenvinkel $\mathrm{dkk}^{5}$ terhadap penderita gagal ginjal kronik predialisis, menunjukkan adanya penurunan parameter nutrisi berdasarkan albumin serum dan indeks massa tubuh yang sesuai dengan kelompok malnutrisi berdasarkan penilaian SGA (SGA B dan C). Pada penelitian ini meskipun status nutrisi sebagian besar subjek 
masuk dalam katagori malnutrisi (SGA B dan C) (Tabel 2) namun parameter nutrisi lainnya yaitu albumin dan IMT masih dalam batas normal. Perbedaan ini mungkin dapat diterangkan dengan melihat perbedaan LFG pada penelitian ini relatif masih baik (stadium 3 ) bila dibandingkan dengan penelitian lainnya dengan LFG terminal sebesar $7 \mathrm{~mL} / \mathrm{mnt}$. Demikian pula pada hasil penelitian lain, parameter nutrisi albumin dan IMT menurun secara bermakna pada LFG di bawah $21 \mathrm{~mL} / \mathrm{mnt}^{10}$

Untuk keperluan penelitian subjek kemudian dikelompokkan dalam kriteria status nutrisi baik atau buruk berdasarkan nilai masingmasing parameter dengan menggunakan metode MUAC dengan hasil hanya terdapat dua subjek dengan gizi buruk dengan nilai LFG yang cukup berbeda masing-masing $17,54 \mathrm{~mL} / \mathrm{mnt}$ (stadium 4 PGK) pada kelompok gizi buruk dan $33,05 \mathrm{~mL} / \mathrm{mnt}$ pada kelompok gizi baik (stadium 3 PGK) seperti terlihat pada Tabel 4.

Penilaian status nutrisi dengan menggunakan satu parameter saja secara klinis, biokimia, ataupun antropometri dapat memberikan hasil yang berbeda-beda baik nilai ataupun interpretasinya, mengingat keterbatasan masing-masing pengukuran dan banyak faktor lain yang mempengaruhinya. ${ }^{10,13}$ Menurut DOQ ${ }^{3}$ dan beberapa rujukan lainnya ${ }^{21}$ dari parameter yang digunakan dalam penilaian status nutrisi, belum ada satupun parameter yang ideal sebagai satu-satunya cara untuk menentukan status nutrisi pasien penyakit ginjal kronik. Kombinasi pengukuran dengan menggunakan beberapa parameter dianjurkan, sehingga dapat meningkatkan sensitivitas pengukuran namun tidak selalu parameter yang digunakan akan memberikan hasil sesuai satu dengan lainnya.

Penelitian yang dilakukan oleh Suhardjono $^{18}$ pada populasi penderita gagal ginjal terminal yang menjalani hemodialisi reguler, menunjukkan hasil yang selaras dan berkorelasi secara signifikan antara albumin serum, IMT, dan SGA sebagai parameter yang digunakan. Mengingat populasi yang berbeda dengan penelitian ini, maka terdapat faktor lain yang mempengaruhi memburuknya status nutrisi sehingga memberikan hasil pengukuran yang selaras, antara lain adanya inflamasi, perbedaan penyakit dasar dan komorbiditas dengan penyakit kronik lainnya serta pengaruh prosedur dialisis itu sendiri.

\section{LFG Terhadap Masing-masing Variabel Nutrisi dan Gabungan}

Hubungan antara laju filtrasi glomerulus terhadap masing-masing variabel status nutrisi (SGA, albumin serum, dan indeks massa tubuh) tampak pada Tabel 5. Dengan perhitungan statistik uji rank-Spearman diperoleh kesimpulan hubungan LFG dengan masing-masing variabel nutrisi yang tidak bermakna $(p>0,5)$.
Demikian pula dilakukan uji statistik Mann-Whitney untuk melihat hubungan nilai LFG terhadap status nutrisi gabungan yang telah dikelompokkan dalam dua kategori yaitu gizi baik dan gizi buruk. Hasil perhitungan memberikan kesimpulan tidak terdapat hubungan bermakna besarnya LFG terhadap status nutrisi buruk atau baik $(p>0,05)$ (Tabel 6$)$.

Hasil penelitian menunjukkan korelasi yang tidak bermakna LFG dengan masingmasing parameter nutrisi maupun gabungannya.

\section{Keterbatasan Penelitian}

Penelitian ini menggunakan metode potong lintang (cross sectional) yang dipilih untuk menguji adanya hubungan laju filtrasi glomerus dengan status nutrisi pada penderita penyakit ginjal kronik predialisis. Keterbatasan metode ini adalah tidak memungkinkan melihat faktorfaktor yang mempengaruhi sebab dan akibat, tidak diketahui insidensi yang diteliti terjadi sebelum atau sesudah terpajan penyakit yang diderita, sehingga sulit melakukan perbandingan (komparabilitas) dan tidak dapat melihat perubahan yang terjadi dengan berjalannya waktu.

Keterbatasan waktu penelitian yang membatasi jumlah subjek yang terkumpul dan persiapan pengukuran pasien mungkin tidak sesuai dengan prosedur yang diharuskan serta keterlibatan banyak orang dalam pengambilan pengukuran dapat menurunkan validitas pengukuran. Faktor eksternal lain yang mungkin mempengaruhi adalah kemungkinan intervensi yang telah dilakukan sebelumnya, baik penyuluhan, diet yang baik, atau obat-obatan akibat komorbid dengan penyakit lain yang dapat mempengaruhi kondisi subjek penelitian.

Secara substansial berdasarkan teori dan literatur, terdapat hubungan laju filtrasi glomerulus dengan status nutrisi pada penderita penyakit ginjal kronik, namun secara statistik penelitian ini menghasilkan kesimpulan tidak bermakna terhadap hipotesis yang dibuat. Dibandingkan dengan penelitian lain, kemungkinan tidak adanya perbedaan LFG terhadap parameter nutrisi disebabkan oleh rata-rata LFG subjek masih cukup baik (> 30 $\mathrm{mL} / \mathrm{mnt}$ ). Kondisi ini tidak memberikan pengaruh uremia terhadap penderita, asidosis, serta gangguan hormonal yang masih terkendali. Tidak adanya inflamasi atau penyakit penyerta lainnya yang mempengaruhi dan memperberat fungsi ginjal, dan adanya intervensi yang tidak diketahui (berupa diet dan obat-obatan) sehingga dapat mengendalikan dan mengatasi komorbid yang diderita. Kondisi lain yang dapat menerangkan hal ini adalah asupan makanan dan protein pada subjek penelitian masih cukup tinggi untuk mengatasi kemungkinan penurunan nutrisi meskipun terdapat faktor lain yang dapat 
menurunkan nutrisi antara lain inflamasi. Dengan kata lain penurunan status nutrisi pada subjek penelitian ini tidak semata-mata disebabkan penurunan laju filtrasi glomerulus itu sendiri namun banyak faktor lain yang berpengaruh (confounding factors) yang tidak menjadi perhatian secara adekuat yang sebenarnya masih terkendali dengan baik.

Berdasarkan analisis statistik beberapa kondisi yang mungkin mempengaruhi hasil penelitian adalah sebagai berikut:

$$
\text { Kesalahan estimasi (prakiraan) }
$$

meliputi:1) Nonsistematik (chance) yang diakibatkan oleh variasi sampel penelitian (besar sampel yang diambil, prosedur sampling) dan kelemah-an sampel (variasi individu, LFG masih baik, intervensi); 2) sistematik (bias) yang diakibatkan oleh desain penelitian yang dibuat (cross sectional) yang mungkin tidak cukup memadai untuk desain penelitian ini.

Bias pengukuran yang diakibatkan:1) Alat ukur yang digunakan, apakah masingmasing dengan standar pengukuran yang baku; 2) cara pengukuran, apakah sesuai dengan standar perlakuan yang diharapkan (SOP); 3) orang yang mengukur, apakah digunakan satu orang terhadap semua pengukuran atau melibatkan banyak orang (validitas menurun).

Kesimpulan: hubungan antara laju filtrasi glomerulus dan perubahan status nutrisi penderita penyakit ginjal kronik predialisis sangat kecil. Ukuran sampel sebesar 72 subjek tidak mampu mendeteksi secara bermakna hubungan tersebut. Dengan demikian diperlukan penelitian lebih lanjut dengan lebih memperhatikan dan memperhitungkan faktorfaktor lain yang terkait secara teliti dan dengan jumlah subjek yang lebih besar untuk melihat hubungan LFG dengan status nutrisi penderita penyakit ginjal kronik predialisis.

\section{DAFTAR PUSTAKA}

1. Schieppati A, Pisoni R, Remuzzi G. Pathophysiology and management of chronic kidney disease. Dalam: Greenberg A. penyunting. Primer on kidney disease. Edisi ke-4. USA: Elsevier Saunders; 2005. h. 44454.

2. National Kidney Foundation, Kidney Disease Outcome Quality Initiative (K/DOQI). Clinical practice guidelines for chronic kidney disease: evaluation, classification and stratification: Part 6. Association of level of GFR with complication in adults. New York: 2002.

3. Fouque D. Influence of dietary protein intake on the progression of chronic renal insuficiency. Dalam: Koople, Massry, penyunting. Nutritional management of renal disease. Edisi ke2. USA, Lippincott Williams \& Wilkins; 2004. hlm. 241-59.

4. Bossola M, Tazza L, Giungi S, Luciani G. Anorexia in hemodialysis patients: an update.
Kidney International. 2006;70;417- 22.

5. Stenvinkel $P$, Heimburger $O$, Paultre $F$, Diczfalusy U, Wang T, Berglund L, dkk. Strong association between malnutrition, inflammation, and atherosclerosis in chronic renal failure. Kidney International. 1999;55:1899-11.

6. Mehrotra R, Kopple ZJD. Causes of proteinenergy malnutrition chronic renal failure. Dalam: Koople, Massry, penyunting: Nutritional management of renal disease. Edisi ke2. USA: Lippincott Williams \& Wilkins; 2004. hlm. 167-82.

7. Caimi G, Carollo C, Presti RL. Pathophysiological and clinical aspects of malnutrition in chronic renal failure. Nutrition Research Rev. 2005;18:89-97.

8. Weiner DE, Tighiouart $\mathrm{H}$, Stark PC, Amin MG, Macleod B, Griffith JL, dkk. Kidney disease as a risk factor for recurrent cardiovascular disease and mortality. Am J Kidney Dis. 2004;44:198206.

9. Barany P. Malnutrition, infalmmation, atherosclerosis syndrome in chronic kidney diseaseimplication for anemia management. Nephrol Hypert. 2007;21:265-8.

10. Don BR, Kaysen GA. Assessment of inflammation and nutrition in patients with endstage renal disease. Review article. J Nephrol. 2003;13:249-59.

11. Saxena A, Sharma RK. An update on methods for assessment of nutritional status in maintenance dialysis patients. review article.Untitled Doc.

12. Atasoyu EM, Evrenkaya TR, Unver S,Tulbek MY. Subjective global assessment does not correlate with laboratory parameters of nutrition in hemodialysis patients. Nephrol Dial Transplant. 2001;34:368-75.

13. Zadeh KK, Ikizler TA, Block G, Avram MM, Koople JD. Malnutrition-inflmation complex syndrome in dialysis patients: causes and consequences. Am J Kidney Dis. 2003;42:86481.

14. Filho RP, Lindholm B, Stenvinkel $P$. The malnutrition, inflammation, and atherosclerosis (MIA) syndrome - the heart of the matter. Nephrol Dial Transplant. 2002;17:28-31.

15. Stenvinkel $P$, Heimburger $O$, Lindholm $B$, Kaysen GA, Bergstrom J. Are there two types of malnutrition in chronic renal failure? Evidence for relationships between malnutrition, inflammation and atherosclerosis (MIA syndrome). Nephrol Dial Transplant. 2002;19:953-60.

16. Kopple JD, Greene T, Chumlea WC, Hollinger $\mathrm{D}$, Maroni JB, Merririll D, dkk. Relationship between nutritional status and the glomerular filtration rate: results from the MDRD study. Kidney International. 2000;57:1688-703.

17. Supariasa IDN, Fajar I, Bakri B. Penilaian status gizi. Jakarta: EGC; 2001.

18. Suhardjono. Hubungan inflamasi kronik polimorfisme gen IL-6-174, dan IL-10-1082 dengan sindrom inflamasi malnutrisi pada 
pasien hemodialisis. Disertasi. Jakarta: FKUI; 2004.

19. Budiarto E. Metodelogi penelitian kedokteran, sebuah pengantar. Jakarta: Penerbit Buku
Kedokteran EGC; 2003.

20. Schulz KF, Grimes DA. The LANCET, handbook of essential concepts in clinical research. USA: Penerbit Elsevier; 2006. 